\title{
SOCIAL AND PSYCHOLOGICAL CAUSES OF GENDER INEQUALITY IN PRESENT-DAY FEMALE CAREER DEVELOPMENT
}

У статті автором актуалізується питання гендерної рівності як необхідної умови досягнення жінками кар'єри. Проблеми гендерної рівності розглядаються крізь призму вияву гендерної нерівності та ї̈ впливу на можливості кар'єрного розвитку жінками. Проаналізовано основні показники гендерної нерівності у сфері зайнятості: гендерна сегрегація праці; ефект «скляної стелі»; нерівність в оплаті праці; подвійна зайнятість жінок (сім'я та робота); гендерні стереотипи; гендерні домагання та насильство. Запропоновано основні шляхи подолання гендерної нерівності у сфері зайнятості: правове та гендерне просвітниитво, подолання гендерних стереотипів, розвиток професійних компетентностей особистості, реалізачія політики гендерної рівності в усіх сферах діяльності.

Ключові слова: гендерна нерівність, гендерна сегрегація, гендерні стереотипи, гендерні домагання та насильство, кар'єрний розвиток.

The article actualize the issue of gender equality as a precondition for successful female career pursuit. We study issues of gender equality in the light of gender inequality manifestation and its influence on female career opportunities. We have analyzed primary indicators of gender inequality with regard to employment, such as gender segregation, glass ceiling effect, gap in wages, dual employment of women (family and work), gender stereotypes, gender-based harassment and violence. We suggest primary ways to reduce gender inequality with regard to employment, such as legal and gender-sensitive education, challenging gender stereotypes, developing personal expertise, implementing gender equality policy into various sectors.

Keywords: gender inequality, gender segregation, gender stereotypes, gender-based harassment and violence.

While nowadays women tend to receive further or higher education, join the labor market and pursue a career, findings of social research conducted in Ukraine, Europe and throughout the world reveal gender inequality in regard to employment. Gender gap shows unequal achievements of men and women in the labor market, as well as limited access of women to rights and assets worldwide. Not a single country in the world has managed to bridge the gender gap.

Some researchers point out that gender inequality in the labor market, Ukrainian labor market in particular, was not caused by pure economic reasons, but rather social or social and psychological factors, based on gender stereotypes with regard to male and female career opportunities and expertise, as well as their standards of behaviour, motives and values. Gender inequality has negative effect on professional fulfillment and slows economic growth of both a person and the state as a whole.

Gender inequality manifestations may effect both men and women. However, researchers typically point out violations of professional self-fulfillment opportunities and gender-based discrimination at the workplace particularly in relation to women. Therefore, attention should be paid to indicators of gender inequality in career pursuit and their impact on female career development [7].

Issues of gender inequality at the workplace have been widely addressed by Ukrainian and foreign sociologists, economists, psychologists. For example, issues of 
gender inequality in the Ukrainian labour market have been explored by $\mathrm{V}$. Vasiuta, K. Voznyi, N. Herasymenko, T. Martseniuk, O. Shestakovskyi and other researchers. A number of papers are concerned with the gender aspect of career pursuit (I. Dembytska, L.M. Karamushka, M. O. Miroshnychenko, L. E. Orban-Lembryk, V. M. Safonova, H. V. Turetska, Ya.I. Shkurko, L. Pochubet and V. Chyker). The issues of gender-based discrimination, harassment and violence, gender stereotypes, in particular in the labor market, have been addressed by T. Hovorun, O. Kikinedzhi, T. Martsyniuk, I. MalkinaPykh, M. Tkalych, D. Greenberg, F. Hutagalung, H. Samuels.

O. Bodnarenko, O. Derkach, A., A. Husieva, L. Karamushka, V. Kazmirenko, V. Pochubet, V. Chyker, Tkach and other researchers have made significant contributions to recent efforts to explore psychological aspects of career pursuit. L. Karamushka, T. Zaichykova, V. Ivkin, O. Kredentser, O. Miroshnychenko, O. Fil have addressed the issue of gender-sensitive aspects of career development.

Although the issue of gender inequality has been receiving much attention from present-day researchers, the necessity to study the influence of indicators of gender inequality on female career development opportunities is becoming relative.

The aim of this paper is to analyze primary social and psychological causes of gender inequality at the workplace and their impact on present-day female career development.

According to EIGE, in 2015, Gender Equality Index for Europe is 52.9. According to World Economic Forum, in 2015, Ukraine ranked the 67th among 142 countries, deteriorating its 2014 rate by 11 points from ranking the 56th [7].

Key indicators of gender equality are financial independence and career prospects, education, health level, as well as political rights and opportunities. These findings prove topicality of the study of gender inequality manifestation with regard to employment, as well as finding ways to reduce it [7].

In most cases, when it comes to gender inequality, attention is drawn to gender segregation in employment. Gender segregation refers to distribution of men and women in certain occupational structures or sectors $[2 ; 4 ; 5]$.

For example, the following fields of activity are considered female-dominated: education, medicine, human resource management, art, entertainment, mass media, service industry (beauty shops, fitness centers), elderly care and child care, diverse fields of trade, agriculture. The following fields of activity have been labeled as male: law enforcement agencies, IT technologies, crisis management, raw materials extraction, manufacturing, construction, repair work $[1 ; 2 ; 13]$.

The same trend is observed when men and women choose their major in college.

Glass ceiling effect is a manifestation of gender segregation. It manifests itself in a set of rules and practices which set up barriers for promoting women to top management $[2 ; 5]$.

In Ukraine, top manager and senior executive positions in various sectors are occupied by men mostly. Even if working in female-dominated sectors, men often hold senior positions.

According to the expert and analytical center for the International HR Portal HeadHunter Ukraine, men apply for leadership positions more often than women. 
Most women are in charge of businesses in such spheres as fitness and beauty, art and media, science and education, tourism, commerce, and marketing. But even in these areas, women represent less than half of all managers. The smallest percentage of women work in such economy segments as raw materials extraction, crisis management, IT technologies, manufacturing, real estate and construction. Most male-dominated are managerial positions in raw materials extraction,manufacturing, construction, crisis management and IT technologies. In these areas, men make a successful career much more often than women [3].

We have analyzed possible barriers to female promotion in management [9]:

- Prevailing gender stereotypes which result in gender-based discrimination, as well as wrongheaded view of female professional competence, etc.;

- gender roles attitudes. It is common in the society that employees of the organization usually have certain expectations about the behaviour of female managers;

- double standards as to men and women exercising their managerial skills. Autocratic leadership style is considered effective for men in management, while for women it is unacceptable ("backbiter»);

- women in management usually have to work more and harder to prove their expertise;

- workers do not always accept a female manager as a source of responsibility and power, they are not ready to work under direction of a woman (men in particular);

- gender pay gap.

In this day and age women rarely get lower wages just because of their gender identity.

Gender inequality is manifested not only in levels and spheres of male and female employment, but also in wages, employment opportunities, and unemployment.

Rate of remuneration for men and women is affected by a number of indirect factors, associated with gender stereotypes, gender roles attitudes at the workplace, sectors of employment and full-time work opportunities. Major such factors include [1]:

- person's educational background and acquired skills (people without secondary or tertiary education find it hard to get a permanent job with a good salary);

- experience and occupational attainment;

- fields of activity. Female employment appears to be concentrated in highly qualified jobs that require brain work and creative operation, but yield lower salaries as they are mostly in the public sector. Men are mostly either employed in blue-collar jobs or hold managerial positions at different levels (often senior), or in the field of cutting-edge technology or other areas with high standard of wages;

- promotion opportunities (it is a well-known fact that wages are higher in managerial positions. Moreover, men are known to dominate in top management);

- female «double workload» (in a family) when a woman spends efforts and time not only for her career, but also for child-rearing and household, which may be a limiting factor for her career development; 
- gender stereotypes and biases related to female career opportunities and career paths;

- full-time or part-time work opportunities;

- conventional approaches to performance assessment geared towards demands of jobs dominated by men;

- field of activity and general business conditions of the company;

- working conditions (harmful conditions are not recommended for women). We find that for highly paid jobs, gender pay gap is bigger than for low-paid.

It is worth noting that the issue of gender pay gap in our society, although not of a pronounced nature, can indirectly manifest itself through a number of factors.

The data show that male and female educational background influences their employment. The research reveals that the highest level of employment is among people with higher educational attainments. This connection is more straightforward among women. Men tend to show fast employment growth if they have senior secondary education, while women achieve a higher level of employment if they attain higher education. It is worth noting that persons with higher educational attainments show the minimum gender gap in terms of employment [1].

European researchers point out that educational background affects job search opportunities [12]. Among other things, they find that gender aspect is important when men and women look for a job to correspond to their educational background and skills [11].

The problem people with senior secondary and higher education encounter is that the labor market in Ukraine is characterized by a conflict between skill level and job or branch requirements. That is, a population group with higher education work in the profession they have not trained in or their level of education goes beyond job requirements. In other words, employees do not use their professional capacity to the full. This applies to both men and women $[1 ; 11]$.

Low-qualified women find it extremely difficult to get access to well-paid jobs. The data show that women are generally more inclined to engage in unstable jobs than men, regardless of their educational background [8].

Analyzing conditions of individual career development, it is also worth mentioning general cultural traditions that dominate our society. Thus, a present-day woman, pursuing her career, must be competent, flexible and competitive on a par with men. At the same time, the image of a woman as a family hearth keeper, mother, who rears the future generation, is preserved. We can say that present-day women tend to be multitasking: they are busy building a successful career, doing household chores, providing childcare and maintaining relations with their partner [6].

Household chores done by women are viewed as unpaid work, «double workload». Therefore, special attention should be paid to sharing household chores, childcare and opportunities for women to pursue their career.

In our society, it is still believed that the spouse with higher income (i.e. breadwinner of the family, and this is most often the husband) does little or no household chores, and the one whose financial contribution to the family budget is much smaller, does daily chores to make up for it. Thus, household chores are done as if in 
exchange for financial support, and the intra-family burden sharing is perceived as fair and rather reasonable [1].

Childbearing can affect full-time work opportunities, career progression, hiring, especially for managerial positions. According to EIGE, female employment has a strong connection to childcare. In most EU member states, increasing number of children reduces female employment.

On top of that, when hiring staff, some employers consider marital and parental status of women, thus, possibility of sick and maternity leaves in the future. These are factors determining undesirable company employee.

In general, a long career break for women to have children and take care of them in the early years of life not only results in reduction of actual earnings, but also has long-term negative consequences for career progression, leading to limited expertise, obsolete knowledge and skills in our present-day dynamic world of work, thus limiting the prospects for further professional fulfillment.

In an effort to be a good mother and wife, a woman can spend less time pursuing her career. This may cause an inner conflict between career goals, aspirations and family obligations. However, if a woman can balance maternity leave and employment, then the childcare period gives her a chance to try a new business, new career opportunities, thus contributing to professional self-fulfillment.

Therefore, it is absolutely necessary to create favorable environment for women to be able to balance their career and family commitments. We mean both considering this issue when developing company's organizational culture and ability to come to an arrangement with the partner, family burden sharing.

Gender-based harassment and violence are symptoms of gender inequality.

Gender-based harassment is viewed as a bias towards men and women due to their gender identity. This concept is wider than sexual harassment and is much more common in the sphere of employment.

Belief that it is women who should brew coffee at the workplace, as well as do the washing-up after refreshment breaks illustrates gender-based harassment of women in workplace relations. A male employee is placed in charge of an important project only because senior executives think that it is man's job to take up big challenges and women cannot cope with them. Gender-based harassment is part and parcel of gender-based violence.

Gender-based violence or violence against women (according to EIGE) is understood as a violation of human rights and a form of discrimination against women and means all acts of gender-based violence. It results in, or is likely to result in, physical, sexual, psychological or economic harm or suffering.

Sexual harassment at the workplace is more common than sexual abuse. Sexual harassment refers to acts of a sexual nature, either verbal (threats, intimidation, insults, offensive comments) or physical (touching, patting, etc.), that humiliate or offend people having working, official or financial relationship with the offender. It should be noted that sexual harassment can occur not only in vertical professional relationship (between supervisor and subordinate), but also in horizontal (between employees at the same level of career ladder), sometimes between the employee and the client [10]. 
With regard to employment, gender-based violence is used as leverage over employee's decision-making, their career development, employment opportunities, remuneration rate and economic security in general.

Gender-based harassment and violence should be treated seriously not only because the victims suffer, but they also contribute to unfavorable social and psychological climate among personnel, which has negative effect on the productivity.

Gender-based harassment and violence can be disguised and people do not always recognize that they have fallen victim to gender-based discrimination. Low awareness of gender equality, reliance on gender stereotypes shape an attitude to manifestations of gender-based persecution as to a common phenomenon without suspecting any violation of personal dignity based on their gender identity.

We have already mentioned that gender stereotypes provide a basis for gender inequality, gender-based discrimination, harassment and violence.

The following are the most commonly encountered stereotypes that effect attitudes about gender roles in the society and career:

the main purpose of women is childbearing and parenting, as well as homemaking, therefore, women should confine their self-fulfillment to these spheres;

woman's successful career is not her own achievement, but influence of some kinship, financial means, her husband's position, etc.;

women are better at special activities, and thus should work in certain economy sectors (gender segregation in employment);

women are more emotional, less competent than men, therefore, they cannot always tackle job tasks well;

the main purpose of men is to defend his household, family, homeland, as well as breadwinning, career and power structures, therefore, it is men who should pursue career and work in governmental agencies.

Gender stereotypes can have different manifestations. As you can see, they form a biased attitude towards women and their professional competencies, thus creating challenging environment for female career development, urging women to make greater efforts to prove their professional knowledge, skills and expertise.

As you can see, gender segregation, unequal opportunities for integration into managerial roles, gender pay gap, double employment of women, gender-based harassment and violence, gender stereotypes serve as social phenomena which account for gender inequality and set up external barriers to female career development.

At the same time, these phenomena are often interiorized to become internal factors for women, thus, causing stress, imbalance between professional and household roles, diffidence, generating low level of motivation to succeed, raising doubts about possible career development and imposing restrictions in various fields of selffulfillment.

We have outlined primary ways to reduce gender inequality with regard to employment, namely:

- challenging gender stereotypes (public awareness campaign aimed at identifying and studying gender stereotypes of a certain community; analyzing one's own gender stereotypes, examining their sources, etc.); 
- developing wider concepts and beliefs with regard to gender-sensitive issues in the workplace;

- understanding signs and limits of gender-based harassment and violence, their prevention and avoidance;

- developing effective coping strategies for pressure;

- balancing work, family and private life by women;

- developing psychological characteristics and personality features essential for one's occupation, which can contribute to professional development of a person, acknowledgment of their expertise irrespective of gender identity;

- developing harmonious personality (personal growth trainings), self-education and lifelong learning;

- practical trainings for successful career, coaching;

- public legal education (awareness of laws on gender-sensitive issues in the labor market);

- implementing and abiding by gender equality policies in various sectors, fostering organizational culture based on gender equality.

Based on the analysis of literature on gender-related issues, we have arrived at the following conclusions. Gender segregation, glass ceiling effect, gap in wages, dual employment of women (family and work), gender stereotypes, gender-based harassment and violence are indicative of gender inequality at the workplace. These indicators are viewed as social and psychological factors limiting female career development. We suggest primary ways to reduce gender inequality with regard to employment, such as legal and gender-sensitive education, challenging gender stereotypes, developing personal expertise, implementing gender equality policy into various sectors.

Future research could study public opinion on gender inequality manifestation, gender-based discrimination, harassment and violence in Ukrainian organizations, as well as determine the drivers for present-day female career progression.

1. Analitychne doslidzhennia uchasti zhinok u skladi robochoi syly Ukrainy. Zvit. I E. M. Libanova ta in. Kyiv, 2012, 212 s. URL: http://www.idss.org.ua/monografii/2013_ ua_womens\%20participation.pdf.

2. Vorona M. V. Henderna skladova rynku pratsi: sehrehatsiinyi aspekt. Rynok pratsi ta zaynyatist naselennia. 2012, №1 S. 12-15.

3. Henderna nerivnist: zhinky ridko staiut TOP-menedzheramy. URL: http://socportal. info/2015/05/15/genderna.html.

4. Martseniuk T. Henderna sehrehatsiia rynku pratsi: yaki roboty shukaiut zhinky ta choloviky (na prykladi bazy reziume ta vakansii na hh.ua. Zhurnal sotsialnoi krytyky «Spilne». 2013. № 6. S. 89-95.

5. Slovnyk hendernykh terminiv / uklad. Z. V. Shevchenko. URL: http://a-Z-gender.net/ua.

6. Betz N. E. Women's career development / In Denmark F., Paludi Michele A. (Ed.). Psychology of Women: Handbook of Issues and Theories. Westport, Conn. : Praeger, 2008. P. 717-753.

7. Gender Equality Index. URL: http://eige.europa.eu/gender-equality-index.

8. Gender, skills and precarious work in the EU : Research note. URL: http://eige.europa.eu/newsand-events/news/women-low-skills-have-fewer-opportunities-eu-labour-market. 
9. Hoyt Crystal L., Simon S. Social Psychological Approaches to Women and Leadership Theory. Jepson School of Leadership Studies articles, book chapters and other publications. 2017. P. 248. URL: http://scholarship.richmond.edu/jepson-faculty-publications/248.

10. Hutagalung F. Sexual Harassment: A Predictor to Job Satisfaction and Work Stress among Women Employees. Procedia - Social and Behavioral Sciences. 2012. Vol. 65. P. 723-730.

11. Kaminskienè L. Jurgilè V.. Women Overeducation: Falling into Opportunity Trap. 2018. URL: http://gestproject.eu/wp-content/uploads/2017/04/Final-GeStProceedingsKyiv2018.pdf.

12. Lamanauskas V., Augienè D. University student career understanding, work value, competence and study influence on professional career evaluation. Education, policy, management and quality. 2015. № 7 (1). P. 8-26.

13. Work in the EU: women and men at opposite ends. 2017. URL: https://eige.europa.eu/rdc/eigepublications/work-eu-women-and-men-opposite-ends.

УДК 316.64: 316.35

doi: 10.15330/psp.22.40-48

Надія Вітюк, Святослав Вітюк

\section{ОСОБЛИВОСТІ СТАВЛЕННЯ СТУДЕНТСЬКОЇ МОЛОДІ ДО ТЮТЮНОПАЛІННЯ}

У статті репрезентовано результати проведеного авторами емпіричного дослідження проблеми ставлення студентської молоді до тютюнопаління. Обтрунтовано теоретико-методологічну основу дослідження, проаналізовано рівень поширення тютюнопаління в студентському середовищі та окремі аспекти ставлення молоді до паління $і$ куриів, визначено сочіально-психологічні чинники тютюнопаління. За результатами проведеного дослідження визначено основні напрями корекиійно-профілактичної роботи щзодо запобігання розвитку у молоді схильності до тютюнопаління та формування ціннісного ставлення до здоров'я й здорового способу життя.

Ключові слова: ставлення, ставлення до тютюнопаління, залежність від нікотину, ціннісне ставлення до здоров'я, здоровий спосіб життя.

The article presents the results of an empirical study on the problem of the young students' attitudes toward tobacco smoking. The theoretical and methodological basis of the research has been substantiated, the level of tobacco use among students and some aspects of young people's attitudes towards smoking and smokers have been analyzed, and the social and psychological factors of tobacco smoking have been determined. According to the results of the study, the main directions of corrective and preventive work have been identified in order to prevent the development of the tobacco use among young people and to promote a good attitude to health and healthy lifestyles.

Keywords: attitude, attitude toward tobacco smoking, nicotine dependence, good attitude to health, healthy lifestyle.

Актуальність дослідження. Поширення в молодіжному середовищі звички тютюнопаління є досить серйозною соціальною та психологічною проблемою. Попри те, що нині багатьма офіційними і неофіційними каналами трансляції масової інформації систематично поширюються повідомлення про шкідливий вплив нікотину, все ж таки багато молодих людей скептично ставляться до таких месиджів і починають палити ще з підліткового або юнацького віку.

(c) Вітюк Н., Вітюк С., 2018. 